\title{
Masa Depan Jaringan 5G dan Perilaku Komunikasi Digital
}

\author{
Topan Yuniarto ${ }^{*}$ \\ ${ }^{1}$ Litbang Kompas \\ Jl. Palmerah Selatan, Jakarta 10270 - Indonesia \\ *Email korespondensi: topan.yuniarto@kompas.com
}

\begin{abstract}
Abstrak
Tahun 2020 diperkirakan Indonesia akan mulai babak baru jaringan koneksi data secara digital generasi kelima atau dikenal '5G'. Saat ini masyarakat sudah menikmati koneksi jaringan $4 G$ atau generasi keempat yang kecepataan transmisi datanya sudah jauh lebih baik dibanding generasi 3G. Jaringan 5G atau Fifth Generation (generasi kelima) adalah sebuah istilah yang digunakan untuk menyebut generasi kelima sebagai fase berikutnya dari standar telekomunikasi seluler. Teknologi generasi kelima ini direncanakan akan resmi diliris untuk sistem operasi seluler pada 2020. Terkait dengan prospek jaringan 5G, penelitian ini menyoroti soal perilaku masyarakat dalam bermedia, khususnya media digital. Metode penelitian ini adalah dengan jajak pendapat melalui telepon dan survei tatap muka terhadap responden. Hasil jajak pendapat ini menggambarkan perilaku masyarakat bahwa gawai merupakan piranti yang semakin penting bagi audiens untuk digunakan sebagai alat komunikasi, baik mengobrol menggunakan fasilitas aplikasi chatting maupun melalui media sosial. Hadirnya jaringan $5 G$ di masa yang akan datang, akan banyak membuka peluang bagi audiens mendapatkan beragam informasi secara cepat. Bagi sisi produsen konten informasi dan berita, jaringan $5 G$ bisa digunakan untuk memperbanyak jenis dan wujud konten yang diproduksi. Meskipun demikian dibutuhkan regulasi atau undang-undang untuk mengatur pemberlakukan dan pemanfaatan jaringan $5 G$.
\end{abstract}

Kata Kunci: Teknologi komunikasi, Jaringan 5G, Komunikasi digital, Perilaku komunikasi, Gawai

\section{PENDAHULUAN}

Dunia industri media dan komunikasi akan maju selangkah lagi dengan rencana hadirnya koneksi jaringan generasi kelima (5G). Jaringan 5G merupakan evolusi dari jaringan internet cepat 4G LTE (Long Term Evolution), yang saat ini banyak diadopsi di smartphone atau gawai. Nantinya, jaringan $5 \mathrm{G}$ bakal menawarkan internet nirkabel lebih cepat untuk berbagai keperluan. Saat jaringan $5 \mathrm{G}$ kelak bisa dinikmati, kecepatan internet pun akan mempersingkat waktu, misalnya untuk unduhan film beresolusi $4 \mathrm{~K}$, game, perangkat lunak, dan berbagai konten lainnya.

Dengan koneksi 5G, kecepatan internet bisa mencapai 4 Gigabits per second. Kecepatan itu setara 500 Megabytes per second yang membuat pengguna bisa mengunduh game berkapasitas 50GB dalam waktu kurang dari 2 menit. Pengguna juga bisa mengunduh film beresolusi 4K 100GB kurang dari empat menit.

Kecepatan internet 1 Gbps yang ditawarkan beberapa operator penyedia jasa internet memang bukan hal baru, tetapi masih cukup langka lantaran mahalnya biaya yang dikeluarkan untuk infrastruktur, misalnya pemasangan kabel fiber optik dan menghubungkannya ke alamat tujuan. Sementara itu, kecepatan internet nirkabel 5G tak akan semahal internet rumah, sebab tidak membutuhkan pemasangan infrastruktur fiber optik ke rumah. Lalu lintas data internet ke sambungan dalam negeri terus naik. Namun, kenaikannya belum mampu menyaingi laju ke sambungan internasional.

Menurut data PT. IDC Indonesia, lalu lintas data internet dalam negeri pernah mencapai 1,3 gigabyte per detik (Gbps) tahun 2005. Itu terjadi saat aktivitas berinternet sedang sangat tinggi. Pada 2010, puncak lalu lintas tercatat di angka 31 Gbps. Kenaikan pun terus terjadi. Pada 2016, capaian tertinggi ada di angka 277 Gbps.

PT. IDC Indonesia merupakan perusahaan teknologi informasi komunikasi (TIK) yang memfasilitasi 99 persen jalur lalu lintas data internet Indonesia. Perusahaan yang berdiri 13 tahun lalu 
ini juga mengakomodasi semua koneksi internet dan layanan telekomunikasi, baik dari penyedia jasa konten lokal maupun internasional.

Operator telekomunikasi di Indonesia, masih fokus untuk mengakuisisi pelanggan layanan 4 G long term evolution (LTE) pada tahun 2017. Pada akhir 2016, jumlah pelanggan mencapai 173,92 juta pelanggan, dengan komposisi 11 persen pengguna 4G. Untuk 5G masih diperlukan kesiapan dari industri telekomunikasi, perangkat komunikasi, aplikasi, dan pelanggan.

Menurut Huawei, teknologi 5G akan membawa dunia ke era baru yang memungkinkan perangkat lebih mudah terkoneksi dengan satu dengan lain. Diperkirakan, berkat 5G, di masa depan akan ada pengalaman dan aplikasi baru seperti mobil tanpa kemudi, operasi dari jarak jauh, Virtual Reality (VR), dan hiburan berbasis VR.

Teknologi 5G dapat memenuhi berbagai skenario aplikasi dengan koneksi antar benda menjadi skenario yang utama, termasuk sistem mengemudi otonom, kendaraan terkoneksi (V2X), pengiriman melalui drone, dan otomasi robot industri.

Bagian terpenting dari koneksi 5G adalah kemampuannya dalam menghadirkan VR dan Artificial Intelligence atau AI (kecerdasan buatan) yang lebih baik, menghubungkan mesin ke mesin (M2M), dan membawa Internet of Things (IoT) atau benda-benda yang terkoneksi ke dalam jejaring internet ke tahap selanjutnya..

Selain itu, 5G juga dikatakan akan mampu memberikan dukungan kuat pada perkembangan internet dan memberikan pengalaman Mobile Broadband (MBB) melalui pemenuhan kriteria untuk tingkat spektrum yang tinggi, jumlah koneksi yang banyak, dan latensi yang sangat rendah dengan kisaran 1 mili detik, yang memungkinkan operator untuk memberikan lebih banyak koneksi Mobile Network of Things (MoT).

Korea Selatan, Jepang, dan China bakal menjadi pionir dengan memulai penerapan jaringan 5G pada 2018 dan 2020. Sebanyak 28 juta pelanggan 5G diperkirakan bakal terkoneksi pada 2022, yang memberikan peluang relatif besar bagi pemain industri Internet of Things (IoT) atau bendabenda yang terkoneksi ke dalam jejaring internet di Indonesia.

Aplikasi IoT tersebut bisa cukup beragam mengingat nyaris seluruh benda bisa dihubungkan dalam internet dengan sejumlah sensor. Misalnya saja pepohonan yang dipasangi sensor pengukur kadar emisi karbon dioksida atau pemberi pakan otomatis dengan sensor pengukur nafsu makan ikan dilanjutkan mesin yang berkomunikasi dengan mesin lain untuk menghasilkan data guna analisis lanjutan.

Aplikasi digital berbasis internet dinilai telah menjadi kebutuhan masyarakat yang tidak lagi dapat dibendung. Pemanfaatan aplikasi digital dinilai sebagai salah satu bentuk perubahan aspek ekonomi dari konvensional ke digital.

Beberapa tahun lalu orang yang akan menggunakan taksi harus menunggu di tepi jalan atau menelepon ke call center perusahaan taksi. Kini, dengan aplikasi di gawai, orang tinggal memesan taksi atau kendaraan roda empat (mobil) sebagai transportasi umum cukup dengan memencet tombol di smartphone atau gawai. Demikian pula, beberapa tahun lalu orang jika akan naik ojek harus ke pangkalan ojek, namun kini cukup memesan lewat aplikasi di gawai. Tiket pesawat, pulsa listrik, hingga makanann bisa dipesan cukup dengan memencet tombol di gawai.

Namun, ada dugaan bahwa pemanfaatan aplikasi digital telah memengaruhi perilaku konsumtif masyarakat dalam memenuhi kebutuhan. Orang cenderung lebih sering berbelanja lewat online atau daring, karena sangat mudah. Selain itu soal harga barang, perbandingan harga pembelian yang lebih murah jika melalui aplikasi digital, dibandingkan jika membeli di gerai toko.

Aplikasi digital, kecanggihan ponsel dan perkembangan media sosial merupakan bagian dari aspek ekonomi yang tidak bisa ditahan. Aplikasi digital kini telah dimanfaatkan untuk memenuhi kebutuhan dasar seperti transportasi dan layanan rumah tangga.

Banyak kalangan pengamat ekonomi dan telekomunikasi menyarankan pemerintah sebaiknya lebih serius untuk memperbaiki aturan dan regulasi mengenai pemanfaatan sistem digital oleh perusahaan-perusahaan yang menggunakannya.

Lalu, bagaimanakah perilaku masyarakat dalam menggunakan piranti gawai saat ini. Melalui survei dan jajak pendapat, kajian ini akan memotret perilaku digital publik dalam menggunakan 
gawai dan kaitannya dengan teknologi $5 \mathrm{G}$ yang diperkirakan akan diterapkan di Indonesia pada tahun 2020.

\section{KERANGKA TEORI}

Media massa adalah ekstensi manusia (extention of man) atau perpanjangan dari indera manusia (McLuhan, 1964). Media tidak hanya memperpanjang jangkauan kita terhadap suatu tempat, peristiwa, informasi, tapi juga menjadikan hidup kita lebih efisien (Nainggolan, 2017, Ritonga, 2017). Dengan interkoneksi teknologi yang terjadi saat ini Marshall McLuhan (1964) mengambarkan bahwa apa yang terjadi di dunia saat ini adalah sebuah global village (desa global).

McLuhan menggunakan istilah global village dalam bukunya yang berjudul The Guttenberg Galaxy: The Making of Typographic Man (1962) dan dalam buku Understanding Media: The Extensions of Man (1964). Istilah ini ia gunakan untuk menggambarkan bagaimana teknologi komunikasi elektronik mengecilkan bumi menjadi sebuah desa melalui informasi yang instan dan tersedia di mana saja serta kapan saja. Saat ini orang mengacu pada sebuah desa global ketika mereka menggambarkan efek dari World Wide Web.

Dalam bukunya The Rise of the Network Society (2000) Manuel Castells menggambarkan dampak teknologi informasi pada masyarakat tidak lain adalah revolusi yang setara sebanding dengan "Revolusi Industri" tiga abad sebelumnya. Dalam pandangannya, tidak hanya inovasi teknologi yang telah mengubah masyarakat, namun proses inovasi itu sendiri telah dipercepat dengan penerapan teknologi tersebut.

Dalam buku A First Look at Communication Theory (Griffin dan Emory A), McLuhan memetakan sejarah peradaban kehidupan manusia dalam empat periode: pertama, The Tribal Age. Pada era ini dikenal sebagai era purba atau era suku zaman dahulu. Di era itu, manusia hanya mengandalkan indra pendengaran dalam berkomunikasi. Komunikasi pada era ini hanya mendasarkan diri pada narasi, cerita, dongeng tuturan, dan sejenisnya sehingga telinga adalah "raja", atau dalam istilah lama, hearing is believing. Kemampuan visual manusia belum banyak diandalkan dalam komunikasi. Era primitif ini tergusur dengan ditemukannya alfabet atau huruf.

Kedua, The Age of Literacy. Semenjak ditemukannya alfabet, maka cara manusia berkomunikasi banyak berubah. Indera penglihatan kemudian menjadi dominan di era ini, mengalahkan indera pendengaran. Manusia berkomunikasi tidak lagi mengandalkan tuturan, tapi lebih kepada tulisan. Ketiga, The Print Age. Era ini dimulai sejak ditemukannya mesin cetak yang menjadikan alfabet semakin menyebarluas ke penjuru dunia. Kekuatan kata-kata melalui mesin cetak tersebut semakin merajalela. Kehadiran mesin cetak, dan kemudian media cetak, menjadikan manusia lebih bebas lagi untuk berkomunikasi. Keempat, The Electronic Age. Era ini ditandai degan ditemukannya berbagai macam alat atau teknologi komunikasi. Telegram, telpon, radio, film, televisi, VCR, fax, komputer, dan internet. Manusia menjadi hidup di dalam apa yang disebut global village. Media massa pada era ini membawa manusia bersentuhan dengan manusia lainnya, kapan saja, di mana saja, dan seketika itu juga.

Sepanjang sejarah, telekomunikasi sudah ada mengubah efek pada orang yang menggunakannya dan masyarakat tempat mereka tinggal. Apa dampaknya pada ponsel ada pada kita dan budaya kita? Banyak yang menunjukkan manfaat nyata dari ponsel: kenyamanan, keamanan, dan tetap berhubungan kapan saja, dimana saja. (Straubhaar, Larose, Davenport, 2012).

Straubhaar memaparkan pada tahun 2010, ponsel generasi keempat (4G) mulai tersedia, walaupun persaingan antarprodusen ponsel terus terjadi terkait siapa yang benar-benar berhak menyebut dirinya sebagai ponsel 4G karena masalah standar teknis yang ditetapkan. Selanjutnya jaringan 4G disebut sebagai 4G LTE (Long Term Evolution). Jaringan 4G LTE akan lebih mudah sinkronisasi menjadi 5G karena sifat dari 4G LTE yang mudah berevolusi untuk jangka panjang.

\section{METODE PENELITIAN}

Penelitian ini menggunakan pendekatan deskriptis kualitatif dengan metode pengumpulan data melalui jajak pendapat menggunakan telepon di 14 kota besar di Indonesia. Selain itu data diperoleh juga melalui wawancara mendalam dalam bentuk tatap muka di beberapa kota besar terkait 
dengan perilaku digital di masyarakat. Penelitian ini juga mencoba mengangkat prospek jaringan 5G dan keuntungannya bagi masyarakat.

\section{Masa Depan Jaringan 5G}

\section{HASIL PENELITIAN}

Hadirnya akses kecepatan jaringan 5G membuka banyak peluang bagi produsen informasi (media massa) untuk lebih melipatgandakan jenis informasi maupun bentuknya. Konten berbasis video berdefinisi tinggi (4K dan HD) serta visual infografik interaktif akan menjadi masa depan seiring kecepatan jaringan $5 \mathrm{G}$ yang memadai.

Perilaku akses bermedia di bagi publik saat ini sudah sedemikian kompleks. Publik tidak hanya mengandalkan media mainstream (media arus utama) sebagai sumber informasi dan berita, tetapi juga mengombinasikan dengan media berbasis internet dan sosial media.

Facebook (FB) masih menjadi media sosial terpopuler sejagat pada 2017. Berdasarkan data Hootsuite dan Wearesocial menunjukkan bahwa pengguna aktif bulanan FB mencapai lebih dari 2 miliar. Angka tersebut mengalahkan pengguna aktif media sosial lainnya. Ini mengindikasikan bahwa jejaring pertemanan milik Mark Zuckerberg tersebut masih menjadi media sosial favorit di muka bumi.

Youtube, layanan streaming video berada di urutan kedua yang memiliki pengguna aktif terbesar kedua, yakni 1,5 miliar. Kemudian diikuti layanan pengirim pesan Whatsapp memiliki pengguna 1,2 miliar berada di urutan ketiga. Sementara BBM yang sebelumnya sempat menjadi pilihan untuk mengirim pesan bagi para para eksekutif kini mulai ditinggalkan. Pengguna aktif BBM hanya mencapai 63 juta di seluruh dunia.

Dalam laporan Wearesocial dan Hootsuite yang bertajuk Digital in 2017: Southeastasia yang bersumber dari Globalwebindex (TW III dan IV 2016) menunjukkan bahwa media sosial (medsos) yang paling aktif digunakan di Indonesia adalah Youtube, yakni mencapai 49 persen. Berikutnya Facebook sebesar 48 persen. Adapun jumlah pengguna aktif media sosial di tanah air mencapai 106 juta pengguna aktif, atau sekitar 40 persen dari populasi. Adapun aplikasi pengirim pesan dengan pengguna aktif terbesar adalah Whatsapp, yaitu mencapai 38 persen. Sementara pengguna aktif BBM sebesar 26 persen. Angka ini di bawah pengguna aktif FB Mesengger maupun Line.

Dengan jumlah populasi yang sangat besar, Indonesia menyimpan potensi ekonomi digital di masa yang akan datang seiring berkembangnya teknologi dan media sosial. Berdasarkan data Kepios (September 2017), jumlah populasi di Indonesia mencapai 264 juta yang merupakan terbesar di kawasan Asia Tenggara. Dari jumlah tersebut, 55 persen merupakan kaum urban yang tinggal di daerah perkotaan. Adapun penetrasi pengguna internet Indonesia mencapai 133 jiwa atau sekitar 50 persen dari total populasi. Sementara pengguna aktif media sosial mencapai 115 juta atau sekitar 44 persen dari total populasi.

Sementara pengguna telepon seluler (ponsel) mencapai 371 juta atau 141 persen dari total populasi. Artinya bahwa setiap orang menggunakan 1,4 (lebih dari satu) ponsel. Sedangkan pengguna media sosial aktif dengan menggunakan ponsel mencapai 106 juta atau 40 persen dari ponsel terdaftar.

Berdasarkan data enam operator seluler, jumlah kartu seluler (prabayar dan pasca bayar) yang beredar mencapai 392,78 juta unit. Dari jumlah tersebut, Telkomsel memimpin peredaran kartu seluler di Indonesia, yakni mencapai 178 juta unit atau sekitar 45,3 persen dari total. Diikuti Indosat Ooredoo sebanyak 96,4 juta unit (24,54 persen) dan Tri 56,8 juta unit (14,46 persen). Dengan jumlah kartu seluler 392,78 juta dan jumlah penduduk sekitar 262 juta jiwa, maka rasio pengguna kartu seluler terhadap populasi mencapai hampir 150 persen. Artinya setiap penduduk menggunakan lebih dari 1 kartu seluler.

Banyaknya kartu seluler yang beredar antara lain disebabkan oleh masyarakat yang menggunakan kartu lebih dari satu. Terutama untuk panggilan dan penggunaan data menggunakan kartu yang berbeda. Selain itu, banyak kartu yang tidak diregistrasi dengan benar karena hanya untuk sekali pakai dengan alasan mendapat promo kuota dari kartu perdana. 
Di bidang perdagangan online atau daring, Tokopedia merupakan e-commerce Indonesia dengan peringkat teratas. Berdasar Startup Ranking, penyedia lapak bagi para pedagang online (market place) milik William Tanuwijaya dan Leontinus Alpha Edision memiliki score 89.353. Raihan ini mengalahkan score Bukalapak, Blibi maupun startup lokal lainnya. E-commerce yang didirikan pada 6 Februari 2009 dan diluncurkan pada 17 Agustus 2009 tersebut kini menjadi salah satu penyedia market place terbesar di Indonesia. Sebagai informasi, Tokopedia belum lama ini mendapat pendanaan US\$1,1 miliar atau sekitar Rp 14,6 triliun dari e-commerce terbesar di Tiongkok, yakni grup Alibaba.

Selain menjadi startup lokal dengan peringkat pertama, Tokopedia juga menduduki peringkat 34 dunia. Sementara peringkat pertama startup dunia adalah Airbnb dengan score 93.239. Adapun jumlah pengunjung Tokopedia mencapai 54,1 juta per bulan dengan view/visit sebesar 10,45.

Pesatnya kemajuan teknologi telah mengubah cara belanja masyarakat dengan melakukan transaksi perdagangan secara elektronik (e-commerce). Dari awalnya perdagangan berlangsung secara offline, dimana antara pedagang dan pembeli selalu bertemu, tapi sekarang sudah tidak lagi. Konsumen tinggal melihat barang di situs penjual dan jika cocok dapat melakukan pemesanan dan melakukan pembayaran melalui transfer bank atau uang elektronik. Atau melakukan pembayaran jika barang sudah diterima (Cash On Delivery/COD)

Nilai transaksi e-Commerce Indonesia pada 2015 mencapai US\$ 3,5 miliar. Angka tersebut naik 34,6 persen dari tahun sebelumnya. Jika dibandingkan dengan 2011, nilai transaksi perdagangan elektronik di tanah air telah melonjak 250 persen.

Populasi Indonesia yang mencapai lebih dari 250 juta jiwa serta wilayah yang berbentuk kepulauan membuka peluang bisnis perdagangan digital. Selain menghemat biaya, pembeli juga dapat mencari penjual dengan harga terendah dengan membandingkan di berbagai lapak perdagangan elektronik.

Jaringan 5G kian membuka peluang bisnis maupun industri informasi. Kecepatan akses data menjadi kunci akan makin membanjirnya lapak-lapak daring karena akan semakin mudah diakses. Sektor transportasi daring diperkirakan juga akan melakukan inovasi produk.

Namun, secepat dan pesatnya perkembangan teknologi komunikasi tetap dibutuhkan regulasi yang melindungi semua kepentingan, terutama terkait rencana beroperasinya jaringan $5 \mathrm{G}$, misalnya UU Telekomunikasi. Jangan sampai "kue" kecepatan 5G tergerus aturan tidak jelas seperti halnya masa depan aturan televisi digital yang hingga kini terkatung-katung belum selesainya RUU Penyiaran.

\section{Perilaku Digital Masyarakat}

Hasil jajak pendapat Litbang Kompas, Agustus 2017, menunjukkan publik menggunakan smartphone atau gawai tujuannya adalah untuk berkomunikasi (70 persen). Namun jika ditelaah lebih jauh fungsi berkomunikasi ini ternyata lebih banyak digunakan untuk ngobrol atau chatting. Aktivitas menggunakan gawai berikutnya yang cukup sering digunakan adalah mencari informasi, baik googling maupun membaca berita. Meskipun demikian banyak pula yang membaca informasi ataupun berita melalui tautan yang dibagikan lewat media sosial.

Hasil jajak pendapat Kompas juga menemukan aktivitas bisnis dilakukan oleh sebagian kecil responden yang termasuk dalam kelompok usia produktif (31-40 tahun). Pada kelompok usia ini, selain sebagai sumber informasi dan bermedia sosial, gawai juga digunakan untuk berbisnis online (daring).

Dari jajak pendapat Kompas ini pula berhasil dipotret perilaku digital dalam hal pembelian paket data internet. Konsumsi paket data untuk mengakses konten digital ataupun bermedia sosial oleh responden jajak pendapat ini juga beragam, namun umumnya biaya yang dikeluarkan untuk membeli paket data berkisar antara Rp 50.000-100.000 per bulan. Semakin menjamurnya koneksi wifi (Wireless Fidelity) di berbagai tempat memungkinkan konsumsi paket data lebih hemat.

Jajak pendapat ini juga mengungkap, saat ini setiap orang setidaknya rata-rata menggunakan empat sumber berita. Surat kabar, televisi, media sosial, situs berita daring, dan mesin pencari 
menjadi sumber berita yang paling banyak digunakan. Adapun blog, majalah, tabloid, dan radio merupakan sumber berita yang relatif sedikit digunakan.

Hasil jajak pendapat Kompas ini juga mengungkap, dari beragam jenis sumber berita tersebut, televisi masih menjadi primadona dan menduduki tempat teratas sebagai sumber berita, diikuti oleh koran dan media sosial. Alokasi waktu yang digunakan untuk mencari berita, rata-rata kurang dari 1 jam. Selebihnya, responden menggunakan gawai untuk chatting atau berkomunikasi menggunakan sosial media (facebook, instagram, dll)

Terekam pula dari jajak pendapat Kompas ini bagaimana pola dan perilaku mengonsumsi media digital oleh publik. Pola jam atau waktu konsumsi media publik dari hasil penelitian ini juga terungkap. Di pagi hari (jam 07.00-9.00) masyarakat menggunakan empat platform (surat kabar, instant messanging atau chatting, televisi dan sosial media). Khusus sosial media dan instant messanging relatif digunakan sepanjang waktu, dari pagi-malam. Televisi menjadi puncak lagi sebagai media yang paling banyak dikonsumsi mulai pukul $17.00-23.00$.

Terkait dengan penggunaan gawai oleh responden jajak pendapat Kompas ini, responden mengaku dalam setahun rata-rata mereka mengganti smartphone atau piranti gawai sebanyak 1-2 kali. Rata-rata smartphone atau gawai yang dibeli berkisar antara 1-3 juta rupiah.

\section{KESIMPULAN}

Teknologi 5G menjadi teknologi yang selangkah lebih maju dengan menawarkan kecepatan koneksi hingga 100 kali lipat. Dibutuhkan regulasi yang melindungi operator jaringan, produsen informasi (media), dan masyarakat sebagai konsumen informasi agar tidak terjebak pada praktik monopoli maupun oligopoli, sehingga hadirnya jaringan $5 \mathrm{G}$ nantinya benar-benar untuk kemajuan kepentingan masyarakat.

Jajak pendapat Kompas memberikan gambaran soal perilaku digital masyarakat bahwa konsumsi media digital di masyarakat saat ini merupakan hal yang tidak terpisahkan dari aktivitas sehari-hari. Jajak pendapat Kompas juga berhasil merangkum perilaku digital masyarakat yang terus menunjukkan tren peningkatan, terutama untuk berkomunikasi seperti mengakses informasi yang berasal dari beragam sumber berita dan menunjukkan tren penggunaan sosial media yang meningkat.

Meskipun demikian, perilaku digital masyarakat masih didominasi oleh perilaku untuk keperluan berkomunikasi semata, masyarakat lebih banyak menggunakan piranti gawai sebagai alat untuk mengobrol atau chatting. Hadirnya teknologi jaringan $5 \mathrm{G}$ akan berdampak besar bagi produsen informasi, produsen perangkat smartphone, operator telekomunikasi, dan masyarakat sebagai konsumen informasi dan produk teknologi komunikasi.

Jaringan 5G dengan konektisi yang makin cepat, akan memiliki masa depan yang baik dalam hal mengembangkan beragam inovasi produk informasi, berita, pengembangan aplikasi gawai, pengembangan aplikasi piranti mesin yang saling terhubung (mesin ke mesin), dan pemberdayaan ekonomi masyarakat melalui perdagangan daring atau online. Hal ini sangat mungkin terjadi seriring dengan respon positif dari operator telekomunikasi, penyedia aplikasi, dan makin banyaknya masyarakat yang terhubung lewat jaringan internet dan jaringan komunikasi data. Tinggal sekarang bagaimana pemerintah mampu menyediakan payung hukum atau regulasi yang menjamin semua tata laksana opersaional $5 \mathrm{G}$ nanti tidak menimbulkan polemik bagi masyarakat dan pemangku kepentingan.

\section{Daftar Pustaka}

Castells, Manuel. (2000). The Rise of the Network Society, United Kingdom: Blackwell Publishing Ltd (2nd edition).

Griffin, Emory A. (2003). A First Look at Communication Theory, 5th edition, New York: McGrawHill.

Joseph Straubhaar, Robert Larose, Lucinda Davenport (2012). Media Now, Boston: Wadsworth, Cengage Learning. 
p-ISSN: 0853-4470 - Vol. 02, No. 01 (2019), pp. 1-7

Logan, Robert K. (2016). Understanding New Media: Extending Marshall McLuhan. New York: Peter Lang Publishing.

Katadata.co.id. (2017). Berapa Jumlah Kartu Telepon Seluler yang Beredar?

Katadata.co.id. (2017). 2011-2015, Nilai Transaksi e-Commerce Indonesia Melonjak 250 Persen.

Liputan6.com. (2016). Seberapa Cepat Internetan di Jaringan 5G?.

Kompas. (2017). Lalu Lintas Data Internet Meningkat.

Kompas. (2017). Mobilitas Digital: Peluang Industri IoT di Indonesia.

Kompas.com. (2017). Menakar Kesiapan Indonesia Menyambut Jaringan 5 G

Nainggolan, B. (2017). Market Typology, Concentration, and Competition of National Media Conglomerate in Indonesia. Jurnal Komunikasi Ikatan Sarjana Komunikasi Indonesia, Vol 2(1), 27-32.

Ritonga. R; Endah M, Syafruddin R. (2017). Gender Awareness of Maria Hartiningsih as Kompas Reporter. Jurnal Komunikasi Ikatan Sarjana Komunikasi Indonesia, Vol 2(2), 82-91. 